The scope of research of the Institute both in pure and applied sciences is increasing, and additional capital and recurring grants are required for the completion of the development and equipment schemes in hand and for providing the workers of the Institute with adequate scales of pay and for increased cost of maintenance and research. Applications have been made to the Central and State Governments for additional grants.

\section{COUNTY DETAILS OF THE CENSUS OF WOODLANDS, 1947-49}

$\mathrm{T}$

HE Forestry Commission Census Reports, Nos.

1 and 2 , dealing respectively with the woods less than and more than five acres in extent (the latter including hedgerow and park timber) have already been reviewed in Nature (August 8, p. 240, and October 3, p. 616), and they have now been supplemented by three further issues-Census Reports Nos. 3, 4 and 5 -giving the details for the Welsh, Scottish and English counties respectively as deduced from the Census of Woodlands 1947-49*. The details are given by counties for these larger woods, the additional figures being for areas only, as the information is not available for standing volume or annual growth. Distribution as between the Forestry Commission and Private Woodlands is shown in all the nine tables given in standard form for each county. National totals are usefully given even where this means some duplication of information given in Report No. 1.

In addition to showing the break-down of the totals of Report No. 1 into county figures, fuller detail is given in certain other respects. Thus the age-class structure of the several categories of high forest is shown by decades for $0-40$ years and by twenty-year periods between 40 and 80 years, followed by two classes for the older woods, namely, $80-120$ and more than 120 years. This detail will be useful for many purposes owing to the big differences in immediate utility, rate of growth, current yields as thinnings, etc., between crops of different age, which are such that the grouping into only two classes above and below 40 years is inadequate.

The fuller detail for the areas under the different tree species is similarly very necessary since the distribution is so widely different from county to county-and here, too, age-classes are differentiated, while separate tables are given for pure stands only as well as for mixed and pure stands together. Thus the basic data are now available for determining what area of spruce or poplar might be available in any section of the country from which to draw supplies for existing or contemplated industries.

Information is also given for six more of the less commonly grown conifers and six more hardwoods, reverling how little we still have of them, even of poplar $(1,466$ acres, though this is only for woods more than five acres in extent). It can similarly now be seen where the scrub and devastated woodlands are concentrated and how much of these areas is thought to be suitable for economic management.

These reports are in foolscap size, the counties being arranged in alphabetical order, and the tables

* Forestry Commission. Census of Wondlands 1947-49: Woods of Five Acres and Over. Census Report No. 3 , Welsh County Details ; pp. viii $+90 ; 48$. Od. Census Report No. 4 , Scottish County Details;
pp. vii $+187 ; 10 s .0 d$. Census Report No. 5, English County Details;
pp. vi $+270 ; 128.6 d$. (London: H.M.S.O., 1953.) are reproduced in a clear and convenient form so that reference is easy. The only regret is that one has to be content with area data where one usually needs volumes.

H. G. Champion

\section{OXIDATION OF PHENYL- HYDRAZINES IN THE PRESENCE OF OXYHAMOGLOBIN AND THE ORIGIN OF HEINZ BODIES IN ERYTHROCYTES}

\author{
By DR. G. H. BEAVEN
}

Medical Research Council Spectrographic Unit, The London Hospital, E.I and $D_{R}$. J. C. WHITE

Department of Patho'ogy (Hæmatology), Postgraduate Medical School of London, W.I2

THE occurrence in phenylhydrazine (Ph.NH.NH ${ }_{2}$ ) poisoning of a hæmolytic anæmia with Heinz inclusion bodies in the erythrocytes is well known. Such inclusions also form rapidly in normal erythrocytes on in vitro incubation at $37^{\circ}$ with phenylhydrazine ${ }^{1}$ With destromatized oxyhæmoglobin solution and excess of various substituted phenyl hydrazines, the oxyhæmoglobin is degraded and precipitated as a 'green hæmoglobin' with composition similar to that of the Heinz bodies, while the hydrazine undergoes oxidation. The process is strictly aerobic, though at low oxygen tension other changes in the oxyhæmoglobin may occur with the more reactive hydrazines, such as choleglobin formation without any formation of green precipitate. The aerobic oxidation of long-chain, unsaturated fatty acids is also catalysed by oxyhæmoglobin, which is decomposed and converted to colourless substances ${ }^{2}$. In these reactions, oxyhæmoglobin is "the catalyst of its own destruction"s, while acting as the last link in the utilization of molecular oxygen ${ }^{4}$.

\section{Oxidation of Arylhydrazines}

Experiments were performed in Dreschel bottles, and volatile products of oxidation swept over by air or oxygen into ethanol. In the presence of oxy. hæmoglobin, excess phenylhydrazine and acetylphenylhydrazine (Ph.NH.NH.COMe) yield as endproducts nitrogen and benzene, the latter being detected by its ultra-violet absorption spectrum.

When present in excess, the oxyhæmoglobin is itself oxidized to methæmoglobin (MetHb), and with 2:4-dinitrophenylhydrazine and asym-diphenylhydrazine this reaction alone occurs, no green hæmoglobin being formed.

Benzene is not formed from phenylhydrazine or acetylphenylhydrazine in the presence of reduced hæmoglobin $(\mathrm{Hb})$ and nitrogen, and similarly with methæmoglobin only a trace of benzene is formed, but a much larger production occurs on admission of oxygen. With oxyhæmoglobin, less benzene is formed under anaerobic than under aerobic conditions. Spectroscopic evidence suggests that reduction of oxyhæmoglobin or methæmoglobin precedes degradation. Similar aerobic reactions, with insoluble 'green hæmoglobin' production, occur with phenylhydrazine$p$-sulphonic acid; with 0 - or $p$-nitrophenylhydrazine, the volatile oxidation product is nitrobenzene. 